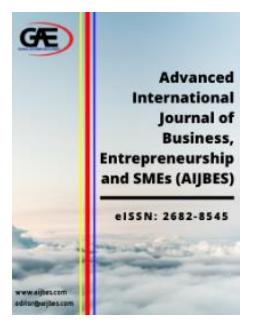

\author{
ADVANCED INTERNATIONAL JOURNAL OF \\ BUSINESS, ENTREPRENEURSHIP AND SMES \\ (AIJBES) \\ www.aijbes.com
}

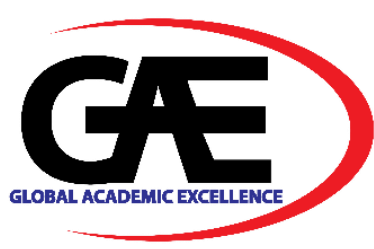

\title{
THE INFLUENCE OF BRANDED WEB SERIES TOWARDS PURCHASE INTENTION OF TELECOMMUNICATION PROVIDER (CASE STUDY: XL AXIATA)
}

\author{
Gabriel Audelia Martiawan ${ }^{1 *}$ \\ 1 School of Business and Management, Institut Teknologi Bandung \\ Email: gabriel_audelia@sbm-itb.ac.id \\ Corresponding Author
}

\section{Article Info:}

Article history:

Received date: 01.08.2021

Revised date: 15.08 .2021

Accepted date: 09.09.2021

Published date: 15.09.2021

\section{To cite this document:}

Martiawan, G. A. (2021). The Influence Of Branded Web Series Towards Purchase Intention Of Telecommunication Provider (Case Study: XL Axiata). Advanced International Journal of Business, Entrepreneurship and SMEs, 3 (9), 313-333.

DOI: $10.35631 / A I J B E S .39021$.

This work is licensed under $\underline{\mathrm{CC} B Y}$ 4.0

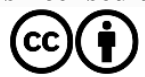

\begin{abstract}
:
The branded web series is one of the latest innovations in the field of the online video advertisement. Unlike advertisements in general that offer products explicitly, branded web series is a form of branded entertainment in the form of a short film format which is packaged into several episodes in the duration of about 5-15 minutes and placed on YouTube. This research aims to know the influence of branded web series on the purchase intention of XL as a telecommunication provider after watching the branded web series Memilih Maju. 138 data were collected through an online questionnaire and analyzed using the PLS-SEM method to assess the relationship between entertainment, informativeness, irritation, advertising value, brand awareness, brand attitude, brand image, and flow toward purchase intention. The results show that entertainment and informativeness have a positive and significant correlation with advertising value, advertising value has a positive and significant correlation with brand attitude, brand awareness, and brand image, brand awareness has positive and significant result with brand image, brand attitude positively significant towards purchase intention, lastly brand image positively significant with brand attitude. Moreover, this research is expected to provide benefits for readers, PT. XL Axiata Tbk., and marketers to develop marketing communication in the form of branded web series.
\end{abstract}

Keywords:

Branded Web Series, Online Video Advertisement, Purchase Intention, XL Axiata, YouTube 


\section{Introduction}

DOI 10.35631/AIJBES.39021

Industrial era 4.0 marked the development of today's digital technology and leads to the increasing number of Indonesia internet usage, from 143.26 million people in 2017 to 171.17 million people in 2018 (Asosiasi Penyelenggara Jasa Internet Indonesia, 2018). This situation has changed the Indonesian people lifestyle in obtaining information, communicating, shopping, and entertainment such as listening to music, watching movie, and gaming. The results of APJII survey in 2018 regarding the behavior of internet users in Indonesia (Figure 1.1.) shows that 45.3 percent of Indonesian people visit entertainment internet content for watching movies or videos.

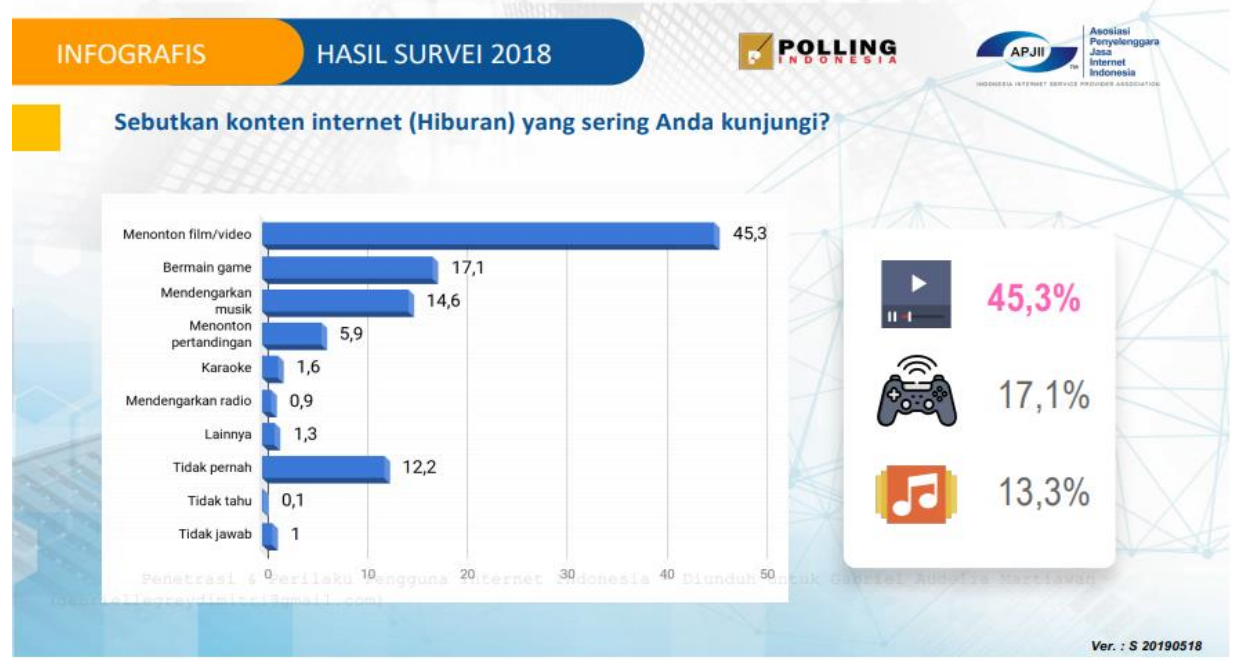

Figure 1: Internet Content (Entertainment) Frequently Visited in Indonesia 2018

Source: APJII2018

The increase of internet usage also generating the development of digital marketing advertising and makes the internet as an essential tool for the company's marketing process to deliver messages and reach consumers. Because of it, majority of businesses in Indonesia are using digital marketing advertising for their business (Winarto, 2020). This combination between advertising and entertainment internet content into online video advertisements can break the clutter and create a new way to get more attention (Kotler \& Armstrong, 2021).

Kujur \& Singh (2018) has found that online video advertisements that use characters and plots have element that can arouse emotional aspects and leads to high ad engagement rather than online video advertisements that only offers product information. This situation is supported by Net TV Project Manager, Kukuh Ari Wibowo statement's that Indonesian market loves "drama" and the demand of drama content is really high. Furthermore, Hudson \& Hudson (2006) stated, there is a need to integrate advertising into entertainment content, where brands are included in the storyline of a film, television program, or other entertainment media, which is called branded content or branded entertainment. It is supported by Dutta (2018) statement: "A brand that tries to make stories about its product or brand exclusively is called branded content". In the current trend, the implementation of brand entertainment or branded content is applied in branded web series (Winarto, 2020). The branded web series is one of the latest innovations in the field of advertising in the form of a short film format from a brand Copyright (C) GLOBAL ACADEMIC EXCELLENCE (M) SDN BHD - All rights reserved 
(Risangdaru, 2018) which is packaged into several episodes in the duration of about 5-15 minutes and placed on a shareable platform such as YouTube.

Most of branded web series in Indonesia are promote FMCG, automotive, or electronic products. However, XL Axiata, a telecommunications company based that provides cellular services also start to use branded web series to promote their product. According to the XL Axiata website, they have won many awards and nominations such as the 2018 Smarties Award, Top 50 Most Valuable Brands in Indonesia, Indonesia Content Marketing Awards (ICMA) 2018, and many more. PT XL Axiata Tbk, or XL for short, is a cellular telecommunications operator in Indonesia. XL started its commercial operations on October 8, 1996 and is the third private company providing GSM cellular telephone services in Indonesia. XL has two GSM product lines, namely XL Prepaid and XL Prioritas (Postpaid). In addition, XL also provides corporate services including Internet Service Provider (ISP) and VoIP (XL Axiata, 2021).

Since August 14th, 2020, XL in collaboration with Net TV has uploaded a new branded web series content: Memilih Maju (Choose to Go Forward). Through this branded web series, XL spread a campaign of "Jaringan Internet Stabil" (Stable Internet Network) and fiberization of XL Axiata 4.5G. This series also awarded as THE INDONESIA YOUTUBE ADS LEADERBOARD: H2 2020 from Google Indonesia.

Memilih Maju branded web series supports young visionaries who dare to face the pandemic by providing stable network services so they can make the right decisions. The story of this branded web series is about four people: Luvita, Dipta, Aska, and Dinda, who struggle with their life. Even though their life is tiring, they must be able to make decision, whether give up or move on. Each of this web series episode has different conflicts and resolutions with average duration time around 7-8 minutes. The first episode of Memilih Maju was published on August 14th, 2021 and ends in 10th episode on October 11th, 2020. Through YouTube, Memilih Maju branded web series is broadcast every Friday on $7 \mathrm{pm}$. This web series was watched up to 5 million times, $66 \%$ more than the KPI target (3 million viewers). This web series also received positive comments because the stories were considered relatable and interesting with a built-in promo that align with the story.

Seeing this phenomenon, the research aims at analyzing the influence of Memilih Maju branded web series towards purchase intention of a telecommunication provider service XL. This research will analyze what factors affect the viewers to have an intention to purchase.

\section{Literature Review}

\section{YouTube}

YouTube is a video-sharing website that allows users to watch content posted by other users as well as upload their own videos (Christensson, 2009). Also, YouTube has become the world's most popular online video site, with users watching 4 billion hours of video per month and there are around 72 hours of video uploaded every minute (YouTube, 2013). In this era, YouTube is a platform for information, learning support, and also for business. Data has shown that 62 percent of companies use YouTube as a platform to post their content (Buffer, 2019). 


\section{Branded Web Series}

Segarra (2017) states that web series is a brand tool to connect different audiences. Meanwhile, Arjona (2012) argues that branded web series is an attractive entertainment advertisement for teenagers and there are activities that have good value among young internet users. Branded web series often arise from the need for advertisers to tell stories through various media and channels, turning into transmediatic narratives that differentiate stories into multimedia, multiway platforms, and hybrids (Simelio and Ruiz, 2013).

\section{Entertainment}

The ability of advertising to meet the audience's needs for feelings of escape, diversion, aesthetic pleasure, or emotional release is defined as entertainment (McQuail, 1983). Advertising entertainment refers to the love for an advertisement, pleasure, and enjoyment that consumers get from advertising (Zhou \& Bao, 2002) to satisfy consumers' hedonic needs (Edwards et al., 2002). Muntinga et al., (2011) also argue that seeking pleasure, relaxation, and spending time are some of the main reasons consumers use social media. Alwitt et al. (1992) also claim that consumers prefer to see advertisements that include a variety of entertainment and pleasure elements.

\section{Informativeness}

Customers view information as a positive aspect of advertising because it allows them to learn about new products, their benefits, and comparative product information (Shavitt, Lowrey, \& Haefner (1998). The extent to which information is helpful and useful to users is referred to as its informativeness. Clancey (1994) argued that as a primary reason for accepting advertisements, media users distinguish advertisements' ability to provide consumer information. On the other hand, Ducoffe (1995) defines informativeness as "Consensus exists concerning the ability of advertising to inform consumers about product alternatives." Erdem et al. (2006) found that customers are more likely to search for product information and obtain more information through an unconditional, interpersonal exchange (De Mooij \& Hofstede, 2010).

\section{Irritation}

Irritation is a measure of how messy and irritating the content is to surfers (Eighmey \& McCord, 1998). According to Benway (1998) and Cho et al. (2004), because of the annoying aspects of internet advertising, people tend to avoid it. When advertising employs intrusive, offensive, or overly manipulative techniques, consumers are more likely to perceive it as unwanted and irritating penetration (Edwards et al., 2002; Pasadeos, 1990).

\section{Advertising Value}

Advertising value is a subjective assessment of the relative value or usefulness of advertising to consumers, and it is an important concept for several reasons (Edwards et al., 2002; Rao \& Minakakis, 2003). When the advertised message is relevant to consumers' needs, they find advertising is valuable. On the other hand, when advertising works effectively, the value of advertising exchanges between advertisers and consumers such as through content (Golding, 2015). Therefore, advertising value as an assessment and a total representation of advertising value on social media.

\section{Brand Awareness}

Brand awareness is defined as brand recognition or memory (Huang \& Sarigollü, 2012). Meanwhile, according to a study conducted by Bush et al. (2004), customers can present Copyright (C) GLOBAL ACADEMIC EXCELLENCE (M) SDN BHD - All rights reserved 
Volume 3 Issue 9 (September 2021) PP. 313-333

DOI 10.35631/AIJBES.39021

purchase intentions as well as positive and negative behaviors to the brand or company. Another study by Khan (2016) shows customers' intentions to purchase something depending on how much awareness the brand has.

\section{Brand Attitude}

Brand attitude as the foundation of consumer action (Keller, 1993) and is a consistent favorable or unfavorable reaction or a learned tendency to a specific object (Hill et al., 1977). According to Kotler et al. (1999), brand attitude is defined as favorable or unpleasant personal evaluations, emotional feelings, and long-term behavioral tendencies. According to Mitchell \& Olson (2000) and Keller (2002), brand attitude is the total or total evaluation of consumers towards a product that has a brand.

\section{Brand Image}

Brand image is a consumer's perception of a particular brand. Keller (2003) defines brand image as a set of associations that consumers perceive a certain brand as known as a brand association. Meanwhile, Temporar (2003) states that "brand image is how the brand is seen".

\section{Flow}

Csikszentmihalyi (1997) in Yang et al. (2017) defines flow as a holistic sensation that people feel when they are absorbed in their activities. This mode is characterized by a tightening of consciousness that filters out irrelevant perceptions and thoughts, a loss of self-awareness and responsiveness to clear goals and unambiguous feedback, and a sense of control over one's environment. In addition, Csikszentmihalyi (1997) characterizes online flow, which involves machine interactivity, enjoyment, loss of self-awareness, and self-reinforcement. Hoffman and Novak (1996) proposed that online flow is a cognitive state that occurs while browsing the internet. This cognitive state has been described as an optimal and intrinsically pleasurable experience.

\section{Purchase Intention}

Purchase intention is a sense of consumer interest so that it can drive the desire to buy and later can also move action in the future to purchase a brand or product that has been informed (Kotler $\&$ Keller, 2016). Purchase intention is the phase of a respondent's proclivity to act before making a purchase (Kinnear, 1995). On the other hand, consumers have a direct influence from online advertising on their purchase intentions. Therefore, the challenge in advertising is to create advertisements that bring value to customers to influence purchase behavior (Schrage, 1994; Neuborne and Hof, 1998). 


\section{Conceptual Framework}

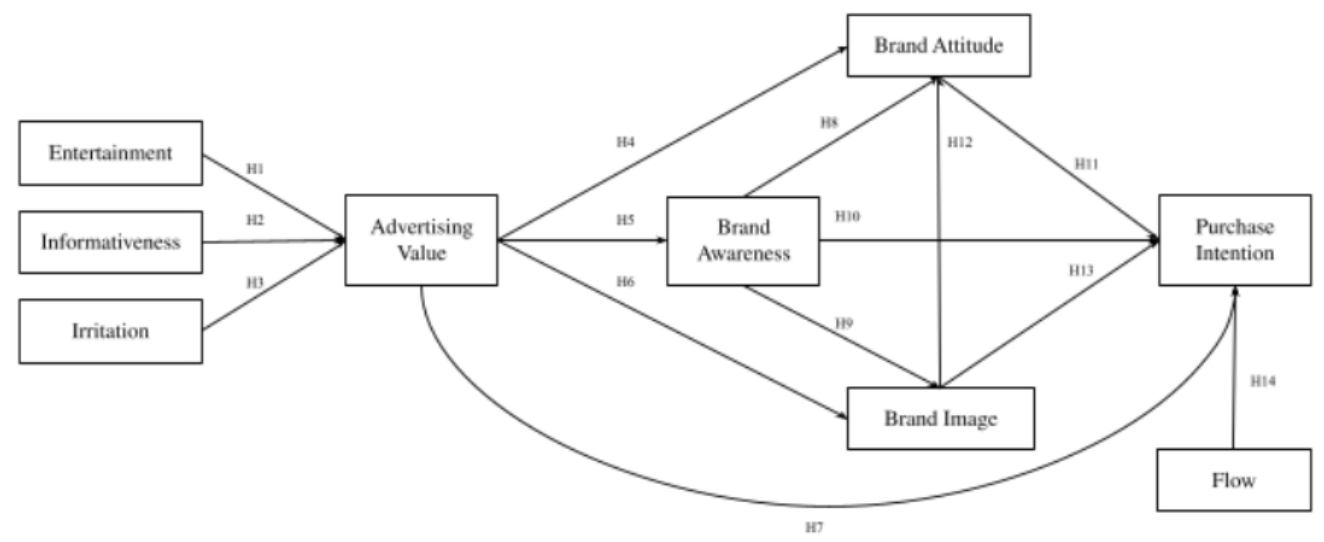

Figure 2: Conceptual Framework

The following hypothesis for this study is as follows:

H1: Entertainment positively affected branded web series advertising value.

H2: Informativeness positively affected branded web series advertising value.

H3: Irritation negatively affected branded web series advertising value.

$\mathrm{H} 4$ : Branded web series advertising value positively affected brand attitude.

H5: Branded web series advertising value positively affected brand awareness.

H6: Branded web series advertising value positively affected brand image.

H7: Branded web series advertising value positively affected purchase intention.

H8: Brand awareness positively affected brand attitude.

H9: Brand awareness positively affected brand image.

H10: Brand awareness positively affected and purchase intention.

H11: Brand attitude positively affected purchase intention.

H12: Brand image positively affected brand attitude.

H13: Brand image positively affected purchase intention.

H14: Flow positively affected purchase intention.

\section{Methodology}

\section{Research Design}

The research process is entailing from conducting exploratory research into phenomena and issues relating to the Memilih Maju branded web series viewer's purchase intention. Followed by problem identification to identify problems occurring. Then comes a review of the literature on previous research findings and hypotheses that can help with this research and understand the concepts and theories. Moreover, a quantitative approach will be used for this study and the data was gathered using online questionnaire. The results of the questionnaire will be examined and evaluated in order to reach a conclusion. 


\section{Population and Sample}

DOI 10.35631/AIJBES.39021

For this research, the quantitative data will collect through online questionnaire and using judgment sampling because the researcher selects viewers who are watching the branded web series "Memilih Maju" minimal 5 episodes to analyze the influence of web series towards purchase intention of XL. Moreover, researcher will collect of 138 respondents employs from Israel's (1992) Evidence of Extension Program Impact sampling methodology. This method stated that the sample size should be determined by the population size and divided into four types of errors: $3 \%, 5 \%, 7 \%$, and $10 \%$, with a confidence level of $95 \%$ and a probability of margin of error $=10$. As a result, the following is the sample size is on Figure 3. Based on the sample size table below, the researcher needs to distribute a minimum of 100 valid questionnaires because the population of total views until episode 5 is 3,661,517.

\begin{tabular}{|c|c|c|c|c|}
\hline \multirow{2}{*}{$\begin{array}{l}\text { Size of } \\
\text { Population }\end{array}$} & \multicolumn{4}{|c|}{ Sample Size (n) for Precision (e) of: } \\
\hline & $\pm 3 \%$ & $\pm 5 \%$ & $\pm 7 \%$ & $\pm 10 \%$ \\
\hline 500 & a & 222 & 145 & 83 \\
\hline 600 & a & 240 & 152 & 86 \\
\hline 700 & a & 255 & 158 & 88 \\
\hline 800 & a & 267 & 163 & 89 \\
\hline 900 & a & 277 & 166 & 90 \\
\hline 1,000 & a & 286 & 169 & 91 \\
\hline 2,000 & 714 & 333 & 185 & 95 \\
\hline 3,000 & 811 & 353 & 191 & 97 \\
\hline 4,000 & 870 & 364 & 194 & 98 \\
\hline 5,000 & 909 & 370 & 196 & 98 \\
\hline 6,000 & 938 & 375 & 197 & 98 \\
\hline 7,000 & 959 & 378 & 198 & 99 \\
\hline 8,000 & 976 & 381 & 199 & 99 \\
\hline 9,000 & 989 & 383 & 200 & 99 \\
\hline 10,000 & 1,000 & 385 & 200 & 99 \\
\hline 15,000 & 1,034 & 390 & 201 & 99 \\
\hline 20,000 & 1,053 & 392 & 204 & 100 \\
\hline 25,000 & 1,064 & 394 & 204 & 100 \\
\hline 50,000 & 1,087 & 397 & 204 & 100 \\
\hline 100,000 & 1,099 & 398 & 204 & 100 \\
\hline$>100,000$ & 1,111 & 400 & 204 & 100 \\
\hline
\end{tabular}

Figure 3: Sampling Size (Oakland, 1953)

\section{Data Analysis}

The collected data for this study will be processed using the Partial Least Squares (PLS) method. The SmartPLS will be used for the validity and reliability tests. The indicator reliability can be assessed by squaring each outer loading to determine the reliability value of an indicator, with a preferred minimum value of 0.7 (Wong, 2013), and the AVE must be at least 0.5 or higher for the validity test (Malhotra, 2007). Also, Wong (2013) claims that determining collinearity can be accomplished by calculating the Variance Inflation Factor (VIF). The preferred score is 5 or lower to avoid the collinearity problem. Next, bootstrapping procedure to generate a T-statistics value that can be used to test the significance (must be greater than 1.96). For the path coefficient to be considered significant by using a two-tailedt-test $5 \%$ of significant level. This research also tested the coefficient of determination $\left(\mathrm{R}^{2}\right)$ and the Stone-Giesser test $\left(\mathrm{Q}^{2}\right)$ to determine the proportion of variance explained by the independent variable in which the dependent variable is above average. The F square effect size is also tested by the researcher to determine the significance of the observed association between differences or correlations. To determine the independent variable's effect on the 
Volume 3 Issue 9 (September 2021) PP. 313-333

DOI 10.35631/AIJBES.39021

dependent variable and mediation variable, total indirect, total effect, and mediation result will be tested.

\section{Discussion and Analysis}

\section{Descriptive Statistics}

Table 1: Descriptive Statistics

\begin{tabular}{|c|c|c|c|c|c|c|c|c|}
\hline No. & Variables & Label & MEAN & $\begin{array}{l}\text { STD } \\
\text { DEV }\end{array}$ & MEDIAN & MODE & MIN & MAX \\
\hline \multirow{5}{*}{1} & \multirow{5}{*}{ Entertainment } & ET1 & 4.08 & 0.83 & 4 & 4 & 1 & 5 \\
\hline & & ET2 & 4.23 & 0.70 & 4 & 4 & 2 & 5 \\
\hline & & ET3 & 4.09 & 0.69 & 4 & 4 & 2 & 5 \\
\hline & & ET4 & 3.69 & 0.83 & 4 & 4 & 2 & 5 \\
\hline & & ET5 & 4.24 & 0.76 & 4 & 4 & 2 & 5 \\
\hline \multirow{3}{*}{2} & \multirow{3}{*}{ Informativeness } & IF1 & 3.91 & 0.79 & 4 & 4 & 1 & 5 \\
\hline & & IF2 & 3.83 & 0.86 & 4 & 4 & 2 & 5 \\
\hline & & IF3 & 3.93 & 0.80 & 4 & 4 & 2 & 5 \\
\hline \multirow{5}{*}{3} & \multirow{5}{*}{ Irritation } & IR1 & 3.92 & 1.01 & 4 & 2 & 1 & 5 \\
\hline & & IR2 & 3.98 & 1.11 & 4 & 1 & 1 & 5 \\
\hline & & IR3 & 4.09 & 1.04 & 4 & 1 & 1 & 5 \\
\hline & & IR4 & 3.57 & 1.14 & 1 & 2 & 1 & 5 \\
\hline & & IR5 & 4.17 & 0.99 & 4 & 1 & 1 & 5 \\
\hline \multirow{3}{*}{4} & \multirow{3}{*}{$\begin{array}{l}\text { Advertising } \\
\text { Value }\end{array}$} & AV1 & 3.91 & 0.74 & 4 & 4 & 2 & 5 \\
\hline & & AV2 & 3.54 & 0.89 & 4 & 4 & 1 & 5 \\
\hline & & AV3 & 3.46 & 0.96 & 3 & 3 & 1 & 5 \\
\hline \multirow{3}{*}{5} & \multirow{3}{*}{$\begin{array}{l}\text { Brand } \\
\text { Awareness }\end{array}$} & BA1 & 4.13 & 0.75 & 4 & 4 & 2 & 5 \\
\hline & & BA2 & 3.90 & 0.85 & 4 & 4 & 1 & 5 \\
\hline & & BA3 & 4.08 & 0.83 & 4 & 4 & 2 & 5 \\
\hline \multirow{4}{*}{6} & \multirow{4}{*}{ Brand Image } & BI1 & 4.07 & 0.74 & 4 & 4 & 2 & 5 \\
\hline & & $\mathrm{BI} 2$ & 4.07 & 0.76 & 4 & 4 & 2 & 5 \\
\hline & & $\mathrm{BI} 3$ & 3.78 & 0.83 & 4 & 4 & 2 & 5 \\
\hline & & BI4 & 3.83 & 0.84 & 4 & 4 & 2 & 5 \\
\hline \multirow{3}{*}{7} & \multirow{3}{*}{ Brand Attitude } & BAT1 & 3.72 & 0.86 & 4 & 4 & 1 & 5 \\
\hline & & BAT2 & 3.80 & 0.89 & 4 & 4 & 1 & 5 \\
\hline & & BAT3 & 3.74 & 0.99 & 4 & 4 & 1 & 5 \\
\hline \multirow{5}{*}{8} & \multirow{5}{*}{ Flow } & FL1 & 3.68 & 0.94 & 4 & 4 & 1 & 5 \\
\hline & & FL2 & 3.96 & 0.87 & 4 & 4 & 2 & 5 \\
\hline & & FL3 & 4.02 & 0.76 & 4 & 4 & 2 & 5 \\
\hline & & FL4 & 3.19 & 1.00 & 3 & 3 & 1 & 5 \\
\hline & & FL5 & 3.43 & 0.96 & 3 & 4 & 1 & 5 \\
\hline \multirow{3}{*}{9} & \multirow{3}{*}{$\begin{array}{l}\text { Purchase } \\
\text { Intention }\end{array}$} & PI1 & 3.71 & 1.02 & 4 & 4 & 1 & 5 \\
\hline & & PI2 & 3.62 & 1.07 & 4 & 4 & 1 & 5 \\
\hline & & PI3 & 3.87 & 1.03 & 4 & 4 & 1 & 5 \\
\hline
\end{tabular}




\section{PLS-SEM Analysis Result}

\section{Outer Model}

Table 2: Composite Reliability

\begin{tabular}{lcl}
\multicolumn{1}{c}{ Variable } & $\begin{array}{c}\text { Composite } \\
\text { Reliability }\end{array}$ & Reliability \\
\hline Advertising & 0.906 & Reliable \\
Value & 0.903 & Reliable \\
Brand Attitude & & \\
Brand & 0.803 & Reliable \\
Awareness & 0.855 & Reliable \\
Brand Image & 0.816 & Reliable \\
Entertainment & 0.853 & Reliable \\
Flow & 0.881 & Reliable \\
Informativeness & 0.914 & Reliable \\
Irritation & 0.922 & Reliable \\
Purchase & & \\
Intention &
\end{tabular}

As shown in Table 2, the consistency reliability score for all variables is greater than 0.7 , indicating that all variables are reliable and consistent in measuring what they are supposed to measure.

Table 3: Convergent Validity

\begin{tabular}{lcc}
\multicolumn{1}{c}{ Variable } & $\begin{array}{c}\text { Average Variance } \\
\text { Extracted (AVE) }\end{array}$ & Validity \\
\hline Advertising Value & 0.764 & Valid \\
Brand Attitude & 0.757 & Valid \\
Brand Awareness & 0.580 & Valid \\
Brand Image & 0.596 & Valid \\
Entertainment & 0.585 & Valid \\
Flow & 0.539 & Valid \\
Informativeness & 0.713 & Valid \\
Irritation & 0.728 & Valid \\
Purchase & 0.798 & Valid \\
Intention &
\end{tabular}

Table 3 shows that all variable values exceed 0.5 which means they are identified as valid. 
Table 4: Outer VIF Value

\begin{tabular}{cc|cc|cc} 
& VIF & & VIF & & VIF \\
\hline AV1 & 1.727 & ET1 & 1.438 & IR1 & 3.618 \\
AV2 & 2.334 & ET2 & 1.584 & IR2 & 3.616 \\
AV3 & 2.364 & ET3 & 1.427 & IR3 & 2.147 \\
BA1 & 1.468 & ET4 & 1.316 & IR5 & 2.445 \\
BA2 & 1.101 & ET5 & 1.270 & PI1 & 1.839 \\
BA3 & 1.495 & FL1 & 1.475 & PI2 & 3.485 \\
BAT1 & 2.345 & FL2 & 1.953 & PI3 & 3.053 \\
BAT2 & 1.776 & FL3 & 1.805 & & \\
BAT3 & 2.055 & FL4 & 1.482 & & \\
BI1 & 1.614 & FL5 & 1.877 & & \\
BI2 & 1.590 & IF1 & 1.646 & & \\
BI3 & 1.772 & IF2 & 1.848 & & \\
BI4 & 1.586 & IF3 & 1.679 & &
\end{tabular}

From the result on Table 4, all VIF values of all indicators passed the preferred criteria. Hence, all indicators inferred from the independent variables, there are no multicollinearity problems.

\section{Inner Model}

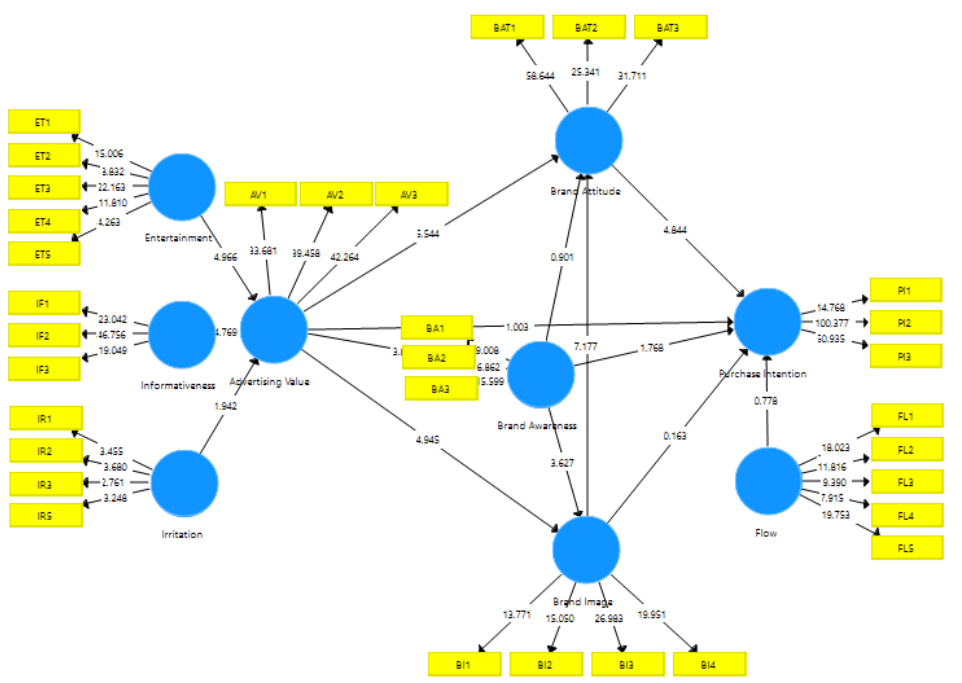

Figure 4: Bootstrapping Result

There are six path coefficients that are not significant since the T-statistics value is below 1.96. The T-statistic of "Advertising Value $\rightarrow$ Purchase Intention" is 0.316, "Brand Awareness $\rightarrow$ Brand Attitude" is 0.368, "Brand Awareness $\rightarrow$ Purchase Intention" is 0.078, "Brand Image $\rightarrow$ Purchase Intention" is 0.871 , "Flow $\rightarrow$ Purchase Intention" is 0,437 and the last, "Irritation $\rightarrow$ Advertising Value" is 0.053 . Besides, the others path coefficients in this inner model are significant. 
Table 5: Coefficient of Determination and Stone-Geisser

Original Sample Standard

Sample Mean Deviation

(O)

(STDEV) $\begin{array}{cc}\text { T Statistics } & \mathbf{P} \\ (|\mathrm{O} / \mathrm{STDEV}|) & \text { Values }\end{array}$
Coefficients of Determination
Crossvalidated Redundancy $\left(\mathbf{Q}^{2}\right)$

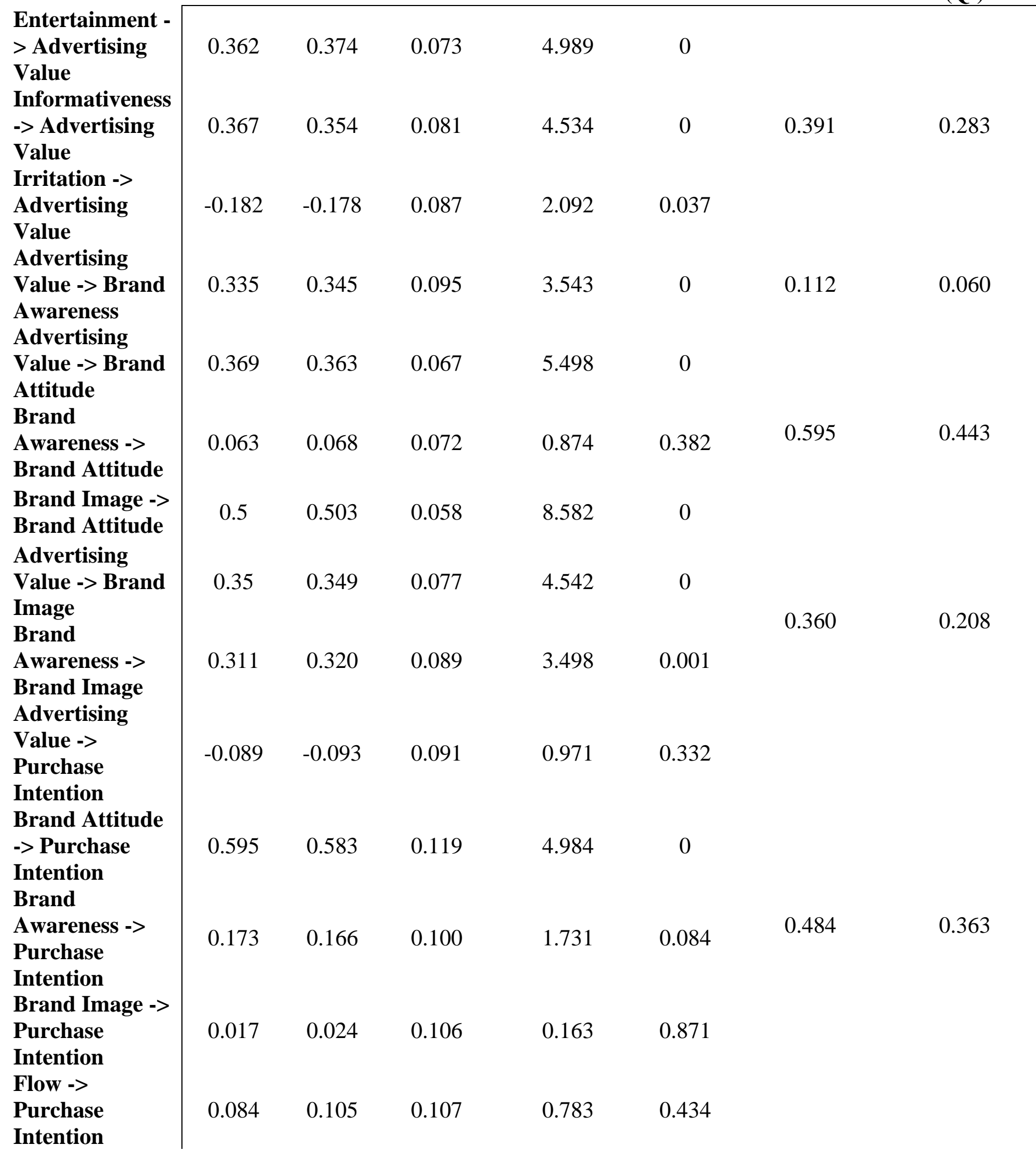


According to Table 5, the $\mathrm{R}^{2}$ (Coefficients of Determination) value of advertising value is 0.391, indicating that the three latent variables (entertainment, informativeness, and irritation) account for 39.1 percent of the variance in customer advertising value. Second, the $\mathrm{R}^{2}$ for brand awareness is 0.112 , which means that one latent variable (advertising value) discusses $11.2 \%$ of the variance in brand awareness. Third, the $\mathrm{R}^{2}$ of brand attitudes is 0.595 , which means that three latent variables (advertising value, brand awareness, and brand image) account for 59.5 percent of the variance in brand attitude. Fourth, the $\mathrm{R}^{2}$ of brand image is 0.360 , indicating that two latent variables (advertising value and brand awareness) account for 36 percent of the variance in brand image. Fifth, the $\mathrm{R}^{2}$ of purchase intention is 0.484 , indicating that five latent variables (advertising value, brand awareness, brand image, brand attitude, and flow) account for 48.4 percent of the variance in purchase intention. Besides that, Wong (2013) mentioned that an $\mathrm{R}^{2}$ value of 0.75 is considered high, 0.50 is considered moderate, and 0.25 is considered low.

The $\mathrm{Q}^{2}$ values for advertising value, brand awareness, brand attitude, brand image, and purchase intention were $0.217,0.120,0.493,2.98$, and 0.381 , respectively. A model is said to be flawless if the value of $\mathrm{Q}^{2}$ equals one (it accurately reflects reality).

Table 6: f square Effect Size Result

\begin{tabular}{|c|c|c|c|c|c|c|c|c|c|}
\hline & $\mathrm{AV}$ & BAT & BA & BI & ET & FL & IF & IR & PI \\
\hline AV & & 0.240 & 0.126 & 0.244 & & & & & 0.008 \\
\hline BAT & & & & & & & & & 0.267 \\
\hline $\mathrm{BA}$ & & 0.008 & & 0.134 & & & & & 0.045 \\
\hline BI & & 0.361 & & & & & & & 0 \\
\hline ET & 0.176 & & & & & & & & \\
\hline FL & & & & & & & & & 0.007 \\
\hline IF & 0.180 & & & & & & & & \\
\hline IR & 0.054 & & & & & & & & \\
\hline PI & & & & & & & & & \\
\hline
\end{tabular}

The F Square Effect Size $\left(\mathrm{f}^{2}\right)$ is a tool for determining the magnitude or strength of latent variables' relationships (Wong, 2013). The goal of this assessment is to determine how useful each concept is for model adjustment (Ringle et al., 2014). The value of $\mathrm{f}^{2}$ greater than 0.35 represents high effect size, 0.15 indicates medium effect size and less than 0.02 indicates small effect size. 
Table 7: Total Effect Result

Purchase Intention

$\begin{array}{lc}\text { Advertising Value } & 0.359 \\ \text { Brand Attitude } & 0.595 \\ \text { Brand Awareness } & 0.305 \\ \text { Brand Image } & 0.302 \\ \text { Entertainment } & 0.130 \\ \text { Flow } & 0.084 \\ \text { Informativeness } & 0.132 \\ \text { Irritation } & -0.065\end{array}$

Hypothesis Test

Table 8: Hypothesis Test Result

\begin{tabular}{|c|c|c|c|c|c|}
\hline Hypothesis & Structural Path & $\begin{array}{c}\text { Original } \\
\text { Sample } \\
(\text { O) }\end{array}$ & $\begin{array}{c}\text { T- } \\
\text { Values }\end{array}$ & $\begin{array}{c}\mathbf{P} \\
\text { Values }\end{array}$ & Result \\
\hline $\mathrm{H} 1$ & $\begin{array}{l}\text { Entertainment }->\text { Advertising } \\
\text { Value }\end{array}$ & 0.362 & 4.989 & 0 & Accepted \\
\hline $\mathrm{H} 2$ & $\begin{array}{l}\text { Informativeness -> } \\
\text { Advertising Value }\end{array}$ & 0.367 & 4.534 & 0 & Accepted \\
\hline $\mathrm{H} 3$ & $\begin{array}{l}\text { Irritation -> Advertising } \\
\text { Value }\end{array}$ & -0.182 & 2.092 & 0.037 & Accepted \\
\hline $\mathrm{H} 4$ & $\begin{array}{l}\text { Advertising Value -> Brand } \\
\text { Attitude }\end{array}$ & 0.369 & 5.498 & 0 & Accepted \\
\hline $\mathrm{H} 5$ & $\begin{array}{l}\text { Advertising Value -> Brand } \\
\text { Awareness }\end{array}$ & 0.335 & 3.543 & 0 & Accepted \\
\hline H6 & $\begin{array}{l}\text { Advertising Value -> Brand } \\
\text { Image }\end{array}$ & 0.420 & 5.010 & 0 & Accepted \\
\hline $\mathrm{H} 7$ & $\begin{array}{l}\text { Advertising Value -> } \\
\text { Purchase Intention }\end{array}$ & -0.089 & 0.971 & 0.332 & Rejected \\
\hline $\mathrm{H} 8$ & $\begin{array}{l}\text { Brand Awareness -> Brand } \\
\text { Attitude }\end{array}$ & 0.063 & 0.874 & 0.382 & Rejected \\
\hline $\mathrm{H} 9$ & $\begin{array}{l}\text { Brand Awareness -> Brand } \\
\text { Image }\end{array}$ & 0.311 & 3.498 & 0.001 & Accepted \\
\hline $\mathrm{H} 10$ & $\begin{array}{l}\text { Brand Awareness -> Purchase } \\
\text { Intention }\end{array}$ & 0.173 & 1.731 & 0.084 & Rejected \\
\hline H11 & $\begin{array}{l}\text { Brand Attitude -> Purchase } \\
\text { Intention }\end{array}$ & 0.595 & 4.984 & 0 & Accepted \\
\hline H12 & $\begin{array}{l}\text { Brand Image -> Brand } \\
\text { Attitude }\end{array}$ & 0.478 & 7.660 & 0 & Accepted \\
\hline H13 & $\begin{array}{l}\text { Brand Image -> Purchase } \\
\text { Intention }\end{array}$ & 0.017 & 0.163 & 0.871 & Rejected \\
\hline H14 & Flow -> Purchase Intention & 0.084 & 0.783 & 0.434 & Rejected \\
\hline
\end{tabular}




\section{H1: Entertainment Positively Affected Branded Web Series Advertising Value.}

Hypothesis 1 assumed that entertainment has a positive effect on branded web series advertising value. As the original sample is 0.362 and T-value scored 4.989 which is greater than 1.96 at a significant point of $0.05(5 \%)$. Therefore, the hypothesis is accepted. It indicates that entertainment has a positive and significant influence on advertising value.

\section{H2: Informativeness Positively Affected Branded Web Series Advertising Value.}

Hypothesis 2 assumed that informativeness has a positive effect on branded web series advertising value. As the original sample is 0.367 and T-value scored 4.534 which is greater than 1.96 at a significant point of $0.05(5 \%)$. Therefore, the hypothesis is accepted. It indicates that informativeness has a positive and significant influence on advertising value.

\section{H3: Irritation Negatively Affected Branded Web Series Advertising Value.}

Hypothesis 3 assumed that irritation has a negative effect on branded web series advertising value. As the original sample is -0.068 and T-value scored 2.092 which is greater than 1.96 at a significant point of $0.05(5 \%)$. As a consequences, this hypothesis is accepted. This clarifies that there is negative effect and significant correlation between irritation and advertising value.

H4: Branded Web Series Advertising Value Positively Affected Brand Attitude.

Hypothesis 4 assumed that advertising value has a positive effect on brand attitude. As the original sample is 0.369 and T-value scored 5.498 which is greater than 1.96 at a significant point of $0.05(5 \%)$. Therefore, the hypothesis is accepted. It indicates that advertising value has a positive and significant influence on brand attitude.

\section{H5: Branded Web Series Advertising Value Positively Affected Brand Awareness.} Hypothesis 5 assumed that advertising value has a positive effect on brand awareness. As the original sample is 0.325 and T-value scored 3.543 which is greater than 1.96 at a significant point of $0.05(5 \%)$. Therefore, the hypothesis is accepted. It indicates that advertising value has a positive and significant influence on brand awareness.

\section{H6: Branded Web Series Advertising Value Positively Affected Brand Image.}

Hypothesis 6 assumed that advertising value has a positive effect on brand image. As the original sample is 0.420 and T-value scored 5.010 which is greater than 1.96 at a significant point of $0.05(5 \%)$. Therefore, the hypothesis is accepted. It indicates that advertising value has a positive and significant influence on brand image.

H7: Branded Web Series Advertising Value Positively Affected Purchase Intention. Hypothesis 7 assumed that branded web series advertising has a positive effect on purchase intention. As the original sample is -0.089 and T-value scored 0.971 which is lower than 1.96 at a significant point of $0.05(5 \%)$. As a consequence, this hypothesis is rejected. This clarifies that advertising value effect negative effect and has no significant correlation between YouTube branded web series and purchase intention.

\section{H8: Brand Awareness Positively Affected Brand Attitude.}

Hypothesis 8 assumed brand awareness has a positive effect on brand attitude. As the original sample is 0.063 and T-value scored 0.874 which is lower than 1.96 at a significant point of 0.05 
Volume 3 Issue 9 (September 2021) PP. 313-333

DOI 10.35631/AIJBES.39021

(5\%). As a consequence, this hypothesis is rejected. This clarifies that even though it has a positive effect, there is no significant correlation between brand awareness and brand attitude.

\section{H9: Brand Awareness Positively Affected Brand Image.}

Hypothesis 9 assumed that brand awareness has a positive effect on brand image. As the original sample is 0.311 and T-value scored 3.498 which is greater than 1.96 at a significant point of $0.05(5 \%)$. Therefore, the hypothesis is accepted. It indicates that brand awareness has a positive and significant influence on brand image.

\section{H10: Brand Awareness Positively Affected And Purchase Intention.}

Hypothesis 10 assumed brand awareness has a positive effect on purchase intention. As the original sample is 0.173 and T-value scored 1.731 which is lower than 1.96 at a significant point of $0.05(5 \%)$. As a consequence, this hypothesis is rejected. This clarifies that even though it has a positive effect, there is no significant correlation between brand awareness and purchase intention.

\section{H11: Brand Attitude Positively Affected Purchase Intention.}

Hypothesis 11 assumed that brand attitude has a positive effect on purchase intention. As the original sample is 0.595 and T-value scored 4.984 which is greater than 1.96 at a significant point of $0.05(5 \%)$. Therefore, the hypothesis is accepted. It indicates that brand attitude has a positive and significant influence on purchase intention.

\section{H12: Brand Image Positively Affected Brand Attitude.}

Hypothesis 12 assumed that brand image has a positive effect on brand attitude. As the original sample is 0.478 and T-value scored 7.660 which is greater than 1.96 at a significant point of $0.05(5 \%)$. Therefore, the hypothesis is accepted. It indicates that brand image has a positive and significant influence on brand attitude.

\section{H13: Brand Image Positively Affected Purchase Intention.}

Hypothesis 13 assumed brand image has a positive effect on purchase intention. As the original sample is 0.017 and T-value scored 0.163 which is lower than 1.96 at a significant point of 0.05 $(5 \%)$. As a consequence, this hypothesis is rejected. This clarifies that even though it has a positive effect, there is no significant correlation between brand image and purchase intention.

\section{H14: Flow Positively Affected Purchase Intention.}

Hypothesis 14 assumed flow has a positive effect on purchase intention. As the original sample is 0.084 and T-value scored 0.783 which is lower than 1.96 at a significant point of $0.05(5 \%)$. Consequently, this hypothesis is rejected. This clarifies that even though it has a positive effect, there is no significant correlation between flow and purchase intention. 


\section{Brand Attitude as Mediating Variable}

Table 9: Total Effect Result of Independent Variable on Dependent Variable

\begin{tabular}{l|cc} 
& $\begin{array}{c}\text { T Statistics } \\
(\mid \text { O/STDEV } \mid)\end{array}$ & P Values \\
\hline $\begin{array}{l}\text { Advertising Value -> Purchase } \\
\text { Intention }\end{array}$ & 1.931 & 0.054 \\
$\begin{array}{l}\text { Brand Awareness -> Purchase } \\
\text { Intention }\end{array}$ & 2.260 & 0.024 \\
$\begin{array}{l}\text { Brand Image -> Purchase } \\
\text { Intention }\end{array}$ & 3.803 & 0
\end{tabular}

According to the results of the Bootstrapping calculation, only two the independent variables (brand awareness and brand image) have a significant effect on the dependent variable. As a result, the first criterion is met.

Table 10: Total Effect Result of Independent Variable on Hypothesized Mediating Variable

\begin{tabular}{l|cc} 
& $\begin{array}{c}\text { T Statistics } \\
(\mid \text { O/STDEV } \mid)\end{array}$ & P Values \\
\hline $\begin{array}{l}\text { Brand Awareness -> Purchase } \\
\begin{array}{l}\text { Bntention } \\
\text { Brand Image -> Purchase }\end{array}\end{array}$ & 1.362 & 0.174 \\
Intention & 9.524 & 0
\end{tabular}

According to Table 10, only brand image shows significant effect on hypothesized mediating variable. Thus, the second criterion is met.

\section{Table 11: Total Effect Result of Independent Variable and Hypothesized Mediating Variable on Dependent Variable}

\begin{tabular}{l|cc} 
& $\begin{array}{c}\text { T Statistics } \\
(\mid \text { O/STDEV } \mid)\end{array}$ & P Values \\
\hline Brand Attitude -> Purchase & 11.535 & 0 \\
Intention & 16.252 & 0
\end{tabular}

Brand image as independent variable has significant relationships with mediating variable (brand attitude) as partial meditation. Hence, the third criterion is met. 


\section{Brand Awareness as Mediating Variable}

DOI 10.35631/AIJBES.39021

Table 12: Total Effect Result of Independent Variable on Dependent Variable

\begin{tabular}{l|lc} 
& $\begin{array}{c}\text { T Statistics } \\
(\mid \mathbf{O} / \text { STDEV } \mid)\end{array}$ & P Values \\
\hline $\begin{array}{l}\text { Advertising Value -> Brand } \\
\text { Attitude } \\
\begin{array}{l}\text { Advertising Value -> Brand } \\
\text { Image }\end{array}\end{array}$ & 12.324 & 0 \\
$\begin{array}{l}\text { Advertising Value -> Purchase } \\
\text { Intention }\end{array}$ & 7.764 & 0 \\
\end{tabular}

According to the Bootstrapping calculation, the independent variable has a significant effect on the dependent variables. As a direct consequence, the first criterion is met.

Table 13: Total Effect Result of Independent Variable on Hypothesized Mediating

\begin{tabular}{l|cc} 
& $\begin{array}{c}\text { Variable } \\
\text { T Statistics } \\
(\mid \mathbf{O} / \text { STDEV }])\end{array}$ & P Values \\
\hline $\begin{array}{l}\text { Advertising Value -> Brand } \\
\text { Awareness }\end{array}$ & 3.905 & 0
\end{tabular}

Based on the calculation using Bootstrapping, advertising value shows significant effect on hypothesized mediating variable. Thus, the second criterion is met.

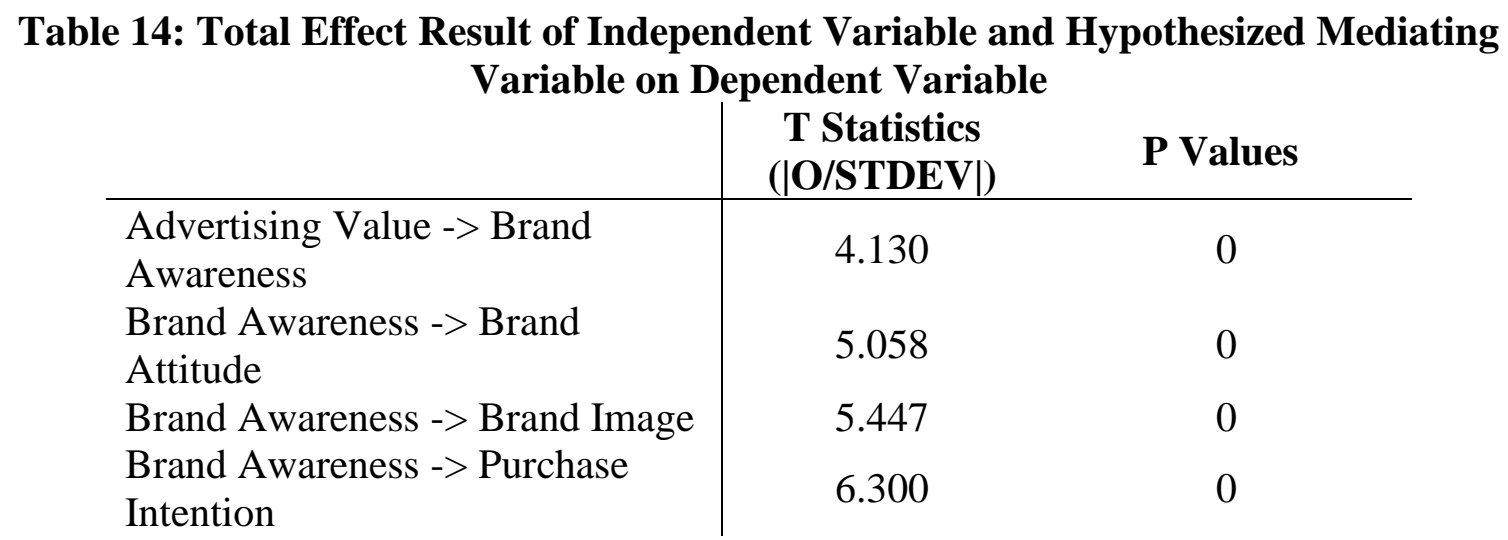

The effect of mediating variable (brand awareness) towards dependent variables (brand attitude, brand image, purchase intention) show significant results. Moreover, there are three independent variables (advertising value and brand image) that have a significant relationship with mediating variables (brand awareness) as partial meditation. Hence, the third criterion is met. 


\section{Brand Image as Mediating Variable}

Table 15: Total Effect Result of Independent Variable on Dependent Variable

\begin{tabular}{l|cc} 
& $\begin{array}{c}\text { T Statistics } \\
(\mid \mathbf{O} / \text { STDEV }])\end{array}$ & P Values \\
\hline $\begin{array}{l}\text { Advertising Value -> Brand } \\
\text { Attitude } \\
\text { Advertising Value -> Purchase }\end{array}$ & 8.002 & 0 \\
$\begin{array}{l}\text { Intention } \\
\text { Brand Awareness -> Brand }\end{array}$ & 3.513 & 0 \\
$\begin{array}{l}\text { Attitude } \\
\text { Brand Awareness -> Purchase }\end{array}$ & 2.901 & 0 \\
Intention & 3.947 & 0
\end{tabular}

According to the Bootstrapping calculation, the independent variables have a significant effect on the dependent variables. As a result, the first criterion is met.

Table 16: Total Effect Result of Independent Variable on Hypothesized Mediating Variable

\begin{tabular}{l|cc} 
& $\begin{array}{c}\text { T Statistics } \\
(\mid \mathbf{O} / \text { STDEV } \mid)\end{array}$ & P Values \\
\hline $\begin{array}{l}\text { Advertising Value -> Brand } \\
\text { Image }\end{array}$ & 4.873 & 0 \\
$\begin{array}{l}\text { Brand Awareness -> Brand } \\
\text { Image }\end{array}$ & 3.692 & 0
\end{tabular}

Based on the calculation using Bootstrapping, advertising value and brand awareness show significant effect on hypothesized mediating variable (brand image). Thus, the second criterion is met.

Table 17: Total Effect Result of Independent Variable and Hypothesized Mediating Variable on Dependent Variable

\begin{tabular}{l|cc} 
& $\begin{array}{c}\text { T Statistics } \\
(\mid \mathbf{O} / \text { STDEV })\end{array}$ & P Values \\
\hline Advertising Value -> Brand & 5.143 & 0 \\
Image & 3.689 & 0 \\
Brand Awareness -> Brand & 16.102 & 0 \\
Image & 7.445 & 0 \\
Brand Image -> Brand Attitude &
\end{tabular}

The effect of mediating variable (brand image) towards dependent variables (brand attitude, purchase intention) shows significant results. Moreover, there are two independent variables (advertising value and brand attitude) that have significant relationships with mediating variables (brand image) as partial meditation. Hence, the third criterion is met. 


\section{Advertising Value as Mediating Variable}

Table 18: Total Effect Result of Independent Variable on Dependent Variable

\begin{tabular}{l|cc} 
& $\begin{array}{c}\text { T Statistics } \\
(\mid \mathbf{O} / \text { STDEV } \mid)\end{array}$ & P Values \\
\hline Entertainment -> Brand Attitude & 3.111 & 0 \\
Entertainment -> Brand & 2.614 & 0 \\
Awareness & 4.483 & 0 \\
Entertainment -> Brand Image & 2.050 & 0.041 \\
Entertainment -> Purchase & & \\
Intention & 6.148 & 0 \\
Informativeness -> Brand & 3.011 & \\
Attitude & 5.155 & 0.003 \\
Informativeness -> Brand & 3.477 & 0 \\
Awareness & 0.135 & 0.001 \\
Informativeness -> Brand Image & 0.086 & 0.893 \\
Informativeness -> Purchase & 0.548 & 0.932 \\
Intention & 0.543 & 0.584 \\
Irritation -> Brand Attitude & & 0.588 \\
Irritation -> Brand Awareness &
\end{tabular}

Based on the calculation using Bootstrapping, only two independent variables (entertainment, informativeness) show significant effect on the dependent variables. Thus, the first criterion is met.

Table 19: Total Effect Result of Independent Variable on Hypothesized Mediating Variable

\begin{tabular}{l|cc} 
& $\begin{array}{c}\text { T Statistics } \\
(\mid \mathbf{O} / \text { STDEV } \mid)\end{array}$ & P Values \\
\hline $\begin{array}{l}\text { Entertainment -> Advertising } \\
\text { Value }\end{array}$ & 4.961 & 0 \\
$\begin{array}{l}\text { Informativeness -> Advertising } \\
\text { Value }\end{array}$ & 4.495 & 0
\end{tabular}

Based on the calculation using Bootstrapping, entertainment and informativeness show significant effect on hypothesized mediating variables (advertising value). Thus, the second criterion is met.

\begin{tabular}{l|cc} 
& $\begin{array}{c}\text { T Statistics } \\
(\mid \mathbf{O} / \text { STDEV } \mid)\end{array}$ & P Values \\
\hline $\begin{array}{l}\text { Advertising Value -> Brand } \\
\text { Attitude }\end{array}$ & 12.960 & 0 \\
$\begin{array}{l}\text { Advertising Value -> Brand } \\
\text { Awareness }\end{array}$ & 3.582 & 0
\end{tabular}


Advertising Value -> Brand

Image

Advertising Value -> Purchase

Intention

Entertainment -> Advertising

Value

Informativeness -> Advertising

Value
7.769

0

5.797

0

5.153

0

4.569

The effect of mediating variable (advertising value) towards dependent variables (brand attitude, brand awareness, brand image, purchase intention) show significant results. Moreover there are two independent variables (entertainment, informativeness) that have significant relationships with mediating variables (advertising value). For this case, two out of three independent variables have a significant relationship with the mediating variable as partial mediating. Hence, the third criterion is met.

\section{Conclusion}

This research objectives are to identify the factors of online video advertisement branded web series influence purchase intention of. The data for this study was gathered through online surveys distributed to viewers of the branded web series Memilih Maju. For quantitative data, the researcher uses PLS analysis. The findings of this study identify factors that influence the purchase intention of viewers of the branded web series Memilih Maju for the PT XL Axiata Tbk. to create marketing communication in the form of branded web series.

Based on the result of PLS analysis, XL purchase intention is influenced by entertainment and informativeness through advertising value. Advertising value and brand attitude also have influence on the XL purchase intention through brand image. Besides that, advertising value and brand image also have influence on purchase intention through brand attitude. Also flow influences purchase intention.

\section{References}

Csikszentmihalyi, M. (2013). Creativity: Flow and the Psychology of Discovery and Invention (1st ed.). Harper Perennial.

Dehghani, M., Niaki, M. K., Ramezani, I., \& Sali, R. (2016). Evaluating the influence of YouTube advertising for attraction of young customers. Computers in Human Behavior, 59, 165-172. doi: 10.1016/j.chb.2016.01.037

Ducoffe, R. H. (1995). How Consumers Assess the Value of Advertising. Journal of Current Issues and Research in Advertising 17(1): 1-18.

Duta, K. D. (2018). Tren Digital Marketing 2019. https://indonesiana.id/read/128939/trendigital-marketing-2019-bag-1-2. Diakses tanggal 10 Januari 2021.

Edwards, S. M., Li, H., \& Lee, J. H. (2002). Forced Exposure and Psychological Reactance: Antecedents and Consequences of the Perceived Intrusiveness of Pop-Up Ads. Journal of Advertising, 31(3), 83-95. https://doi.org/10.1080/00913367.2002.10673678

Erdem, T., Swait, J., \& Valenzuela, A. (2006). Brands as Signals: A Cross-Country Validation Study. Journal of Marketing, 70(1), 34-49. https://doi.org/10.1509/jmkg.2006.70.1.34

Golding, N. (2015, April 20). Choosing the right social media platform to promote your business: One, Two, or all of them? | Natalie Golding. Gabriel. https://blogs.brighton.ac.uk/ng132/2015/04/20/choosing-the-right-social-mediaplatform-to-promote-your-business-one-two-or-all-of-them/ 
Volume 3 Issue 9 (September 2021) PP. 313-333

DOI 10.35631/AIJBES.39021

Huang, R., \& Sarigöllü, E. (2012). How brand awareness relates to market outcome, brand equity, and the marketing mix. Journal of Business Research, 65(1), 92-99. https://doi.org/10.1016/j.jbusres.2011.02.003

Hudson, S., \& Hudson, D. (2006). Branded Entertainment: A New Advertising Technique or Product Placement in Disguise? Journal of Marketing Management, 22(5-6), 489-504. doi:10.1362/026725706777978703

Khan, M. L. (2017). Social media engagement: What motivates user participation and consumption on YouTube? Computers in Human Behavior, 66, 236-247. doi: 10.1016/j.chb.2016.09.024

Kotler, P. G. A. (2021). Principles of Marketing (17th Ed). Pearson India Education.

Malhotra, J. E., \& Rogers, R. W. (1980). Effects of source expertness, physical attractiveness, and supporting arguments on persuasion: A case of brains over beauty. Journal of Personality and Social Psychology, 39(2), 235-244. https://doi.org/10.1037/00223514.39.2.235

Malhotra, N. (2010). Marketing Research: an applied approach: 6th Edition. Pearson education.

Malhotra, N. K., Nunan, D., \& Birks, D. F. (2016). Marketing research. In The Marketing Book: Seventh Edition. https://doi.org/10.4324/9781315890005

McQuail, D. (1983). Mass Communication Theory: An Introduction. London: Sage.

Mkik, M. Khouilid, and A. Aomari, (2017) "Green advertising and environmentally consumption: The level of awareness and Moroccan customer's perception," IOSR Journal of Business and Management, vol. 19, no. 8, pp. 1-11, 2017. Advances in Economics, Business and Management Research, volume 72

Muntinga, D. G., Moorman, M., \& Smit, E. G. (2011). Introducing COBRAs. International Journal of Advertising, 30(1), 13-46. https://doi.org/10.2501/ija-30-1-013-046

Mustikasari, R. P. (2018). Pengaruh Terpaan Web Series Tropicana Slim 'Sore' pada Behavioral Intention. Jurnal Komunikatif, 7(2), 106-129. doi:10.33508/jk.v7i2.1829

Neuborne, E., \& Hof, R. D. (1998), Branding on the net. Business Week, November 9, 76-86

Schrage, M. (1994). Let's make a deal. Advertising Age, August 22

Segarra. (2017). Branded Web Series as an Advertising Strategy: The \#EncuentraTuLugasCase. Jurnal Komunikasi Sosial, 72. ISSN 1138-5820

Tsimonis, G., \& Dimitriadis, S. (2014). Brand strategies in social media. Marketing Intelligence \& Planning, 32(3), 328-344. https://doi.org/10.1108/mip-04-2013-0056

Winarto, W. D. N. (2020). Pengaruh Informativeness, Entertainment, Credibility, Flow Terhadap Nilai Iklan, Sikap Terhadap Iklan, dan Niat Beli (Studi pada Branded Web Series "Janji" Tropicana Slim. Thesis. Tidak Diterbitkan. Fakultas Ekonomi dan Bisnis. Universitas Airlangga: Surabaya.

Wong, K. K. K.-K. (2013). 28/05 - Partial Least Squares Structural Equation Modeling (PLSSEM) Techniques Using SmartPLS. Marketing Bulletin, 24(1), 1-32. Retrieved from http://marketingbulletin.massey.ac.nz/v24/mb_v24_t1_wong.pdf\%5Cnhttp://www.res earchgate.net/profile/Ken_Wong10/publication/268449353_Partial_Least_Squares_St ructural_Equation_Modeling_(PLS-

SEM)_Techniques_Using_SmartPLS/links/54773b1b0cf293e2da25e3f3.pdf

Yang, K., Huang, C., Yang, C., \& Yang, S. Y. (2017). Consumer attitudes toward online video advertisement: YouTube as a platform. Kybernetes, 46(5), 840-853. doi:10.1108/k-032016-0038 